\title{
Analysing Dangerous Emotions: Pragmatics of Jealousy in Othello's Speech
}

\begin{abstract}
To achieve its cathartic effect tragedy must communicate and elicit emotions. Any dramatic utterance, treated as an act of communication within the represented world, rests on the interaction of two inseparable, accordant, and interrelated systems - language and emotions. Language can name and verbalize emotions in order to construct them in the dramatic world, but to create a linguistic image of a believable emotional utterance the language a character speaks must appear to be influenced and shaped by emotions. Further, that mimetic representation of emotion through language must be understood by the audience. To achieve this, dramatic language must either rely on conventional linguistic means used to express emotions or create its own code that will be decoded by the audience. The audience will vicariously experience the characters' emotions by recognizing them in their language and actions.

The emotionally dynamic image of Othello, one of the most passionate men of Elizabethan drama, is created primarily by the language he uses. To follow the changes in the syntax and the semantics of his language as the action of the play develops is to observe the transformation of the character from a loving and caring husband into a jealous beast that knows no mercy. The article will offer an analysis of the pragmalinguistic representation of jealousy in Othello's language and show how his discourse changes in the text. The analysis will rely on basic pragmatic categories and consider Othello's use of directives, assertives, expressives, etc. The emotional change in Othello will also be illustrated by a brief study of the change in his syntax and his vocabulary: from balanced rhetorics and sophisticated words to erratic speech and expletive swearwords.
\end{abstract}

Key words: jealousy, dangerous emotions, pragmatics, discourse, semantic and syntactic structures, text-linguistics.

There is no doubt that Elizabethan dramatists used language to set and create dramatic atmosphere, to define time, place and character. But in Othello, language is not simply the medium by which the drama is conveyed: in this play language is action. According to many researches, one of Shakespeare's most prominent tragedies Othello gains its success and worldwide popularity due to the language 
that managed to transmit the emotions and shows the tragedy of a passionate man, who was taken in by false words. The play shows the power of language, through which characters construct their own and others' identities and exert power either by speaking, remaining silent or silencing others.

Although the interrelation of language and emotional state of characters is vividly seen throughout the whole of Othello, the transformation the leading character undergoes and its simultaneous reflection in the way he speaks are in the focal point. The article presents an analysis of the literary depiction of passion in Othello from the pragmatic and psychoanalytic perspectives. Linguistic means used by Shakespeare to create an image of a passionate man, such as pragmatic functions of the utterances, peculiarities of syntax and style, become the object of the investigation. Following Lacan's vision on the nature of language and its interconnection with the emotional state of the speaker, this paper approaches the interpretation of Othello's speech not only from the linguistic but also from the psychoanalytic perspective. For Lacan language is a sign which reflects the inner state of the speaker - there is nothing in the language that is absent in subject's conscious, sub-conscious, and unconscious ${ }^{1}$. Elements of Lacan's approach in defining "affectivity" help to make assumptions about and categorize the correlation between Othello's emotional state and the peculiarities of his discourse.

In the first, second and at the beginning of the third act of the play Othello, a Moorish general, experienced military leader and a respected by authorities and common people public figure, skillful in communication with the Venetian elite and gifted with natural charisma, addresses to others only as "most potent, grave, and reverend signiors, my very noble and approved good masters" (I.iii.76), "my lieutenant" (I.ii.34), "friends" (I.ii.35), "masters" (II.iii.163). He also uses phrases, which demonstrate his sophisticated language, intelligence, self-confident and unruffled personality. Not only the words he uses, but also the complex sentence structures with dominant affirmative statements, developed lines and argumentative utterances show his rationality, confidence and awareness of his potential and stable position in the society. There are also a lot of punctuation marks such as commas and semicolons in his oration to the Senate, which suggests that his speech is flowing and he is talking slowly, calmly, and carefully.

When it comes to the topics Othello discusses and the set of linguistic means used to express his opinion or address his wife it becomes obvious that he lives in two worlds: the world of the army and the world of the family, where he is equally successful and happy. The prevailing number of affirmative sentences, few questions and negations, vocabulary with positive meaning and the usage of diminutives towards Desdemona ("sweet Desdemon" (III.iii.57), "my Desdemona" (I.iii.295), "sweeting" (II.iii.239), "my fair warrior" (II.i.176), "my soul's joy" (II.i.179), "my dear love" (II.ii.8), "honey" (II.i.200)) prove that Othello at the beginning of the play is an example of a well-balanced person who is satisfied

1 J. Lacan, The Function and Field of Speech and Language in Psychoanalysis [in:] J. Lacan, Ecrits: The First Complete Edition in English, transl. B. Fink, New York 2006, p. 207. 
with the life he lives and manages to remain at least emotionally at a distance from much of the action that concerns and affects him.

The conversation with Iago in Act 3 Scene 3 becomes the turning point and marks not only the change in Othello's speech, but also the transformation of his personality. The rational and wise general turns into a wild and irrational creature, which is suffocating in its jealousy and stormy imagination. The contrast between a self-confident man and his insecure shadow is expressed by the malicious language, which replaces measured, calm and long speech flow in first two acts: the tone becomes darker, the utterances are more metaphorical, and the punctuation is used to stagger the speech, depicting Othello beginning to lose control. Words like "phrase of peace" (I.iii.82) and "I will [...] deliver of my whole course of love" (I.iii.91), which demonstrated Othello's confidence and deep trust in the everlasting love, are displayed in contrast with such collocations as "how shall I murder him?" (IV.i.165) and "I will chop her into messes" (IV.i.194), showing the aggressiveness, savagery and uncontrollable intense emotions, which gained the upper hand over the rational military leader and loving husband. The usage of words such as "murder" in contrast to "peace" and the extreme verbal violence towards Desdemona and Cassio reflect the significant change in Othello's personality, which is imprinted in his words as well as in his actions. The numerous diminutives transformed into a torrent of invectives such as "she is a whore" (IV. ii.86) and "Let her rot and perish and be damned tonight, for she shall not live" (IV.i.176) illustrate Othello's change and his impulsiveness, which replaced the clear vision and his natural perspicacity.

Experienced soldier, who saw through Brabantio's character so well, fails to recognize the truth in Desdemona's words and Cassio's behavior. He also misjudges Iago, calling him "honest" and giving himself completely to his scheming. From this moment onwards Othello gives Iago the leading role and becomes at his command. On the linguistic level such change is reflected in Othello's lines, which become shorter than Iago's. Uncertainty in Othello's behavior and his unwillingness to make decisions and a silent consent to be dependent and led are displayed in unfinished sentences, questions, repetitions and negations.

Dangerous emotions Othello is overwhelmed with can be seen not only in his lines, but also in the communicative situations other characters are involved in. It is worth mentioning that Othello's speech after Act 3 Scene 3 as well as his emotional state undergoes a noticeable transformation, which is reflected not only in the words he uses, but also in the whole structure of his utterances.

James L. Calderwood points out the shift from monologue, which as the form of Othello's speech prevails in the first two acts, to dialogue, which dominates in the other parts of the play ${ }^{2}$. By monologue the researcher understands the pragmatic filling and function of Othello's utterances, which in the first two acts are designed not "to further dialogue, but to suspend it" gests that the speaker is the center of the utterance and that self-confident Othello

2 J.L. Calderwood, Speech and Self in Othello, "Shakespeare Quarterly" 1987, n 38(3), p. 300.

3 Ibid. 
is in control of the situation, he realizes his dominant position in the communicative situation and that is why he needs neither approval nor confirmation from his interlocutors. His speech is not targeted to get the audience's response, it is rather constructed to emphasize the process of thought sharing, which as well as the speaker's speech is measured, well thought and flowing. Even in the opening lines in his speech to the senators - "Most potent, grave, and reverend signiors, / My very noble and approv'd good masters' (I.iii.76-77)" - where Othello uses high style, flattering words to show his inferior position, the structure and literary devices of his lines demonstrate the superior position of the speaker in relation to the audience he addresses. As Calderwood rightly mentions, "the high, almost fawning formality of his opening lines reserves a solemn and sizeable space for his holding forth"4. And this is reflected in Othello's manner of speaking: he, knowing that he will not be interrupted, allows himself to use long sentences, which he complicates with repetitions, reminiscences, subordinate clauses and additions in parenthesis. He also enriches his utterances with literary devices such as antitheses ("That I have ta'en away this old man's daughter, / It is most true" (I.iii.78-79)), parallels ("She loved me for the dangers I had pass'd, / And I loved her that she did pity them" (I.iii.167-168)), litotes and comparisons ("And little of this great world can I speak, / More than pertains to feats of broil and battle, / And therefore little shall I grace my cause / In speaking for myself' (I.iii.86-89)), which, aside from their main function to impress the audience, also display Othello's self-confidence, self-admiration and his awareness of his dominant position in the communicative whole.

However the situation changes in Act 3 Scene 3 when Othello, involved in Iago's scheming, becomes trapped on his territory. Their conversations, dialogical in their structure, become dialogical in their pragmatic function too. Othello, who was dominant and self-reliant in his speech in the first two acts, becomes dependent and inferior in the conversations with Iago in the later acts. He lays down conditions, demands responses and proofs and calls Iago for actions: "if thou dost love me, / Show me thy thought" (III.iii.119-120), "If more thou dost perceive, let me know more;/ Set on thy wife to observe" (III.iii.243-244).

The shift in the hierarchy of their communicative roles becomes more vivid due to the increasing number of questions Othello begs Iago to find answers to: "What dost thou say, Iago?" (III.iii.94), "why dost thou ask?" (III.iii.96), "Why of thy thought, Iago?" (III.iii.99), "Is he not honest?"(III.iii.104), "What dost thou think?" (III.iii.108), "What dost thou mean" (III.iii.157-158), "Dost thou say so?" (III.iii.208). Some questions, which are repeated several times, echoing and disjunctive utterances emphasize Othello's suspicion mixed with impatience and curiosity. This also suggests that Othello is emotionally involved in the communication, which is not typical for him in the Act 1 , where he rather plays the role of a skillful detached narrator than of a passionate speaker. Moreover in his speech to senators there is no space for suggestions and implications. Words, used there, stay for themselves and their meaning does not cover any hidden message. This also proves that Othello performs the role of a narrator who tells the story

\footnotetext{
${ }^{4}$ Ibid.
} 
of the sake of the story and does not need the audience to decode the overtones. Othello's monologues make their own meaning based on the words. In the conversation with Iago the meaning is contained in "unspoken aspects of the scene or immediate context even more than it does in words. With Iago, the unsaid always says more than the said"5. It is important to notice that the main idea in the dialogues with Iago is represented not in the syntactic structures of the utterances as it was in the monologue, "where sentences were built on their predecessors", but rather comes from the outside, when "each utterance answering one before it and preparing for one to follow, a reply that invites a reply"6.

A shift from monological speech to dialogical one can also be explained as the necessity to participate in the social life, the necessity to solve the problem of infidelity, which is constructed within the society and practically does not exist outside its borders. Dialogical manner of speaking also signifies the thought sharing and emotional exchange Othello needs in response to Iago's suspicion. It shows how dependent he is on those who know and how limited common knowledge he as a stranger shares with Venetians is. This explains the number of questions Othello poses, his emotional language, which reflects his irritation of the inability to apprehend Desdemona's betrayal, and the success of Iago's scheming.

Another powerful means to create the image of a passionate man in Othello are the utterances that have performative function in language and communication such as directives, affirmatives, and expressives.

Directives, which are constructed in language mainly due to such sentence structures as imperatives, are viewed as a type of speech acts that expresses the will to influence the behavior of another ${ }^{7}$. In this case an imperative structure signifies a command, entreaty, or exhortation and denotes a person who is in power to restrain, control, and direct. It also illustrates imposition of somebody's will on others and as a mode of narration is typical for a strong personality, who tends to act authoritatively. Pragmatic meaning of an imperative is not one-sided and it varies depending on an interlocutory act it appears in $^{8}$. What all imperatives regardless of the communicative situation they occur in have in common is the speaker's desire as the conventional element of any syntactic structure as such ${ }^{9}$.

Imperatives, which occur in Act 1 Scene 2, the first scene Othello appears on the stage, depict him as a wise, well-balanced soldier, who is very careful with everything he says. His utterances are measured and his orders are rational and well thought. They also express his bravery ("Holla, stand there!" (I.ii.55)), professional wisdom, respect and obedience from his subordinates' side ("Keep up your bright swords, for the dew will rust them. / Good signiors, you shall more command with years / Than with your weapons" (I.ii.59-61) "Hold your hands,

5 Ibid., p. 301.

${ }^{6}$ Ibid.

7 J. Searle, A Classification of Illocutionary Acts, "Language in Society" 1976, n 5.1, p. 1-23.

${ }^{8} \mathrm{H}$. Takahashi, A Cognitive Linguistic Analysis of the English Imperative: With Special Reference to Japanese Imperatives, Philadelphia 2012, p. 11.

9 C. Condoravdi, S. Lauer, Imperatives: Meaning and Illocutionary Force, Colloque de Syntaxe et Semantique a Paris, Universite Paris 8, 21-23 September 2011, conference presentation, p. 7. 
/ Both you of my inclining and the rest" (I.ii.82-83)). For the first time the audience meet the leading character, he is presented as a brave, experienced, rational and unruffled commander, who is in control even in the stressful situations. His commands do not cross the limits of the professional domain and the tone they are pronounced with is cool and official. The same is reflected in Act 2 Scene 1 and 3, when Othello addresses Iago "Go to the bay, and disembark my coffers; / Bring thou the master to the citadel" (II.i.204-205), "Iago, look with care about the town" (II.iii.242), Cassio "Good Michael, look you to the guard tonight" (II. iii.1), "But never more be officer of mine" (II.iii.237) or other soldiers "Hold, for your lives!" (II.iii.153), "For Christian shame, put by this barbarous brawl" (II.iii.159), "Speak: who began this?" (II.iii.165), "Give me answer to it" (II.iii.183).

The character and function of the imperatives used in Act 1 Scene 3 change to meet the pragmatic needs of Othello's speech to the senators. Here the tone is still official and even flattering, although the role the imperatives perform shifts from commands to polite requests, which are used to create the impression of the speaker's inferior position "I do beseech you, / Send for the lady to the Sagittary, / And let her speak of me before her father" (I.iii.113-115). The fact, that imperatives are used by Othello on purpose, only emphasizes how masterly his oratorial skills are and suggests his self-confidence and superiority in the communicative situation "Let housewives make a skillet of my helm, / And all indign and base adversities/ Make head against my estimation!" (I.iii.272-274).

Although he was called by the senators to explain the relationship with Desdemona, it is Othello who performs the leading role in the conversation. And imperatives, as tools for self-expression, prove that: "Ancient, conduct them; you best know the place" (I.iii.121), "let her witness it" (I.iii.170), "Let her have your voice" (I.iii.260). The impression Othello's narrative makes on the audience is reflected in the Duke of Venice's address to Brabantio: "Your son-in-law is far more fair than black" (I.ii.285). As Marcia Macaulay points out "Othello's literal blackness as well as the inappropriateness of his action is eradicated by his very skillful representation of events"10. And imperatives help him to appear more convincing and achieve such an effect.

Imperatives in conversation between Othello and Desdemona, which appears in Act 2 Scene 1 (II.I.178-184), are transformed into imperative utterances and perform the role of private address to Desdemona and are very poetic. They are used to reflect Othello's good mood, his happiness and delight the meeting with Desdemona causes. Several imperatives in Act 2 Scene 3, which are targeted at Desdemona, display how loving, attentive and careful Othello as a husband is "Come, my dear love" (II.iii.8), "All's well now, sweeting; / Come away to bed" (II.iii.239-240), "Come, Desdemona: 'tis the soldiers' life/ To have their balmy slumbers waked with strife" (II.iii.244-245).

The pragmatic function imperatives perform in Act 3 Scene 3, or as Marcia Macaulay called it "the seduction scene"

${ }^{10}$ M. Macaulay, When Chaos Is Come Again: Narrative and Narrative Analysis in Othello, "Style" 2005, n 39(3), p. 262.

11 Ibid., p. 260. 
ders and commands, first to personal requests, then to private demands and finally becomes emotional begging: "Show me thy thought" (III.iii.120), "I prithee, speak to me as to thy thinkings, / As thou dost ruminate, and give thy worst of thoughts / The worst of words" (III.iii.135-137); "If more thou dost perceive, let me know more;/ Set on thy wife to observe. Leave me, Iago" (III.iii.243-244); "Villain, be sure thou prove my love a whore; / Be sure of it; give me the ocular proof" (III.iii.362-363), "Make me to see't; or, at least, so prove it, / That the probation bear no hinge nor loop to hang a doubt on" (III.iii.367-369), "Give me a living reason she's disloyal" (III.iii.412).

Here the main part of the scene is the conversation between two people, which makes it easier to follow the transformation of the emotional state the participants of the communication undergo. This change is depicted in the shift of the pragmatic meaning of imperatives, which transform according to the communicative needs of the speaker. At the very beginning of the Scene 3 Othello is rather curious, and that is why his imperatives perform the function of requests and the address to Iago by his rank is replaced by more private "thou". When Iago manages to plant suspicion in Othello's mind with the help of explicit performatives (I say, I think) and verbs of perception, Othello's speech in general and imperatives in particular become more like demands. After the conversation with Desdemona, when Othello sees the proof of her infidelity in the lost handkerchief, his inflamed jealousy demands some satisfaction. Othello's imperatives become extremely emotional and resemble begging. Furthermore, a negative imperative appears in this scene for the first time ("Fear not my government" (III.iii.259)), which suggests the highly emotional state of the speaker. As Iago makes a remark: "I see, sir, you are eaten up with passion" (III.iii.394).

In Act 4 and 5 the number of imperatives decreases, although their pragmatic meaning becomes emotionally more intense. "Ay, let her rot, and perish, and be damned tonight; for she shall not live" (IV.i.176-177), "Hang her!" (IV.i.182), "Get me some poison, Iago, this night" (IV.i.198). In a conversation with Desdemona Othello's speech gets rather emotionally unstable, diminutives are followed by strict directives, which suggest Othello's irrational aggressive domination caused by jealousy in the interlocutory act: "Pray, chuck, come hither" (IV.ii.5), "Let me see your eyes:/ Look in my face" (IV.ii.7), "Come, swear it, damn thyself" (IV.ii.36), "Ah, Desdemon, away, away, away!" (IV.ii.42), "Turn thy complexion there, / Patience, thou young and rose-lipped cherubin, / Ay, there, look grim as hell!" (IV.ii.63-65), "Get you to bed on th'instant; I will be returned forth-with. Dismiss your attendant there: look't be done" (IV.iii.7-8).

In Act 5 in the dialogue between Othello and Desdemona Othello's speech becomes erratic and chaotic. The phrases he uses reflect his unstable emotional state and imperatives emphasize his dominant position: "Well, do it, and be brief", "Think on thy sins", "Peace, and be still!", "Sweet soul, take heed, / Take heed of perjury: thou art on thy death-bed", "Therefore confess thee freely of thy sin", "Down, strumpet!" (V.ii.31, 41, 46, 51-52, 80).

Another characteristic feature of Othello's passionate discourse is the usage of assertives. Marcia Macaulay points out that only in "Act 1, of the 69 speech acts 
uttered by Othello, $42(60 \%)$ are assertives" ${ }^{\prime \prime 2}$. According to the speech act theory, assertives are considered to be a type of a speech act, the purpose of which is to convey information about some state of affairs of the world from one agent, the speaker, to another, the hearer ${ }^{13}$. Assertives also represent the speaker's beliefs and thoughts, their understanding of the way things are and their confidence in what they are saying. Othello's preference for assertives (which in most cases are embodied in affirmative statements) in Act 1 displays his rationality, self-confidence, openness, directness, and calm. Even in quite stressful situations his language does not change, proving that Othello's emotional state remains stable. When Othello is called to Senators his readiness to be responsible for the relationship with Desdemona and to deliver a speech in front of authorities is expressed in an assertive statement "I must be found. / My parts, my title, and my perfect soul / Shall manifest me rightly" (I.ii.29-31). Such a way to express intentions shows that Othello is "a man of complete self-assurance not only in himself but also in how others will perceive him"14.

Confronted with Desdemona's father, Othello shows no sign of emotion and his language reflects his state: “That I have ta'en away this old man's daughter, / It is most true; true I have married her / The very head and front of my offending/ Hath this extent, no more" (I.iii.79-82). Although the usage of expressives would be more predictable and justified here, the fact that Othello uses assertives to respond to Brabantio's accusation, suggests that he is in control over his emotions and is brave enough to state things the way they are. Partially these skills can be explained by Othello's occupation and military experience, where rational thinking and unruffled equanimity are the key to success. This also suggest that Othello is a skillful orator, who knows how to persuade the audience and with the help of such assertives as "I won his daughter" (I.iii.94) he masterfully does it.

However, the situation in the "seduction scene" changes. Assertives, replaced by expressives and directives, become less frequent, which suggests that Othello's emotional state has changed as well. According to Searle ${ }^{15}$ expressives are meant to express the psychological state of a speaker and his attitude and emotions in the particular communicative situation and are embodied in exclamations, questions and repetitions. Searle believed that directives and expressives comparing to assertives are considered more emotional and their prevailing number in Act 3 Scene 3 and 4 suggests that the speaker whose speech they appear in is in power of passion. It is worth mentioning that exclamatory statements appear in the two acts 6 times more often than in Act 1 and 2 (9 exclamatory statements in Act 1, 2 and 59 in Act 3, 4; Act 5-12). Such a remarkable difference in the leading character's speech can be explained by the transition from rational Othello to a savage tyrant, or, as Lacan called it, "affectivity", which is represented by "the triad" of 3 stages: frustration, aggressiveness and regression ${ }^{16}$.

12 Ibid., p. 261.

13 J. Searle, A Classification of Illocutionary Acts..., p. 10-16.

14 M. Macaulay, op. cit., p. 261.

15 J. Searle, A Taxonomy of Illocutionary Acts [in:] Language, Mind and Knowledge, ed. K. Gunderson, Minneapolis 1975, p. 347.

16 J. Lacan, The Function and Field of Speech and Language..., p. 207. 
Following Lacan's observations on the nature of frustration and its representation in language, we find it very applicable in Othello's case. From Lacan's point of view, frustration is "inherent in the subject's very discourse" and is expressed not with the help of silence but rather with numerous assertive statements, which only emphasize the speaker's isolation, his defense from the others and the incoherence of an image created by a speaker for the others ${ }^{17}$. This approach suggests that affectivity is an innate phenomenon, which does not appear spontaneously. And Othello's speech in the first two acts shows it. Prevailing number of affirmative statements in Act 1 and 2 shows Othello's self-confidence, rationality, calm, but it also signifies that Othello, realizing that he is the other, is constructing a presentable image of himself (a good soldier, a loving husband, an honest member of a society,) with the help of assertives. Such behavior, according to Lacan, is typical for the frustration stage and leads us to aggressiveness, which judging by the character's language develops from frustration and is fully expressed in Act 3 and 4.

The stage of aggression is characterized by "the highly emotional response to any intervention" 18 , which in Othello's case is the reaction to an outside attempt to ruin his image of a perfect family, which in Othello's understanding is "taken away from him by another". Lacan states that aggression may have several ways of expressions from a verbal attack to physical abuse and emotions accompanying aggression may vary from despair to fury ${ }^{19}$. Because the transition from frustration to aggression is not an instant process, there is a vivid transformation from expressives denoting surprise and helplessness to expressives showing irritation, extreme jealousy and anger.

Act 3 Scene 3 is marked with emotional utterances, which convey the meaning of surprise, curiosity, annoyance, indignation ("Zounds! What dost thou mean?" (III.iii.158), "By heaven, I'll know thy thoughts!” (III.iii.166)), and helplessness ("O curse of marriage, / That we can call these delicate creatures ours, / A not their appetites!" (III.iii.271-273), "If she be false, O then heaven mocks itself!" (III. iii.281)). Semantics of the chosen words in utterances and address to the abstract notions and Powers emphasize Othello's feebleness and loneliness. He looses everything he believed in and was defined by. From this moment Othello enters the final stage of aggression, which is marked with highly emotional, rude, sometimes even obscene lexis, which appears in prose utterances, which also signify the inner transformation Othello is undergoing.

This part is also highly saturated with threats, which, according to Buss, signifies destructive consequences which sexual jealousy causes (slapping, brutal beating, intimate partner violence $)^{20}$. Such a behavior Lacan explains as an animalistic instinct, whose function is to mark the territory, to show the domina-

${ }^{17}$ Ibid., 207-208.

18 Ibid.

19 J. Lacan, Aggressiveness in Psychoanalysis [in:] J. Lacan, Ecrits: The First Complete Edition in English, transl. B. Fink, New York 2006, p. 84.

${ }^{20}$ D.M. Buss, Sexual Jealousy, "Psychological Topics" 2013, n 22(2), p. 160. 
tion and to suppress an opponent ${ }^{21}$. He also understands threatening behavior as "passion of the soul", which expresses the person's true need in attention and self-confidence ${ }^{22}$. Wilson and Daly claim that aggression is the way to cope with stress; it is the sign of "experiencing reduced self-esteem, isolation, anxiety and fear" 23 . Obviously, in Othello's case it is the fear to be left and betrayed, and his behavior is the voice of wounded ego and hurt pride, which corresponding with his military experience, force him to attack "the enemy" (Desdemona) before "the enemy" defends herself: "I'll tear her all to pieces" (III.iii.434), "Hang her!" (IV.i.182), "I will chop her into messes - cuckold me!" (IV.i.194).

Animalistic aggression and violence are encoded in each verb used in these lines, moreover impersonal and syntactically solitary interjections like "Lie with her! Lie on her!.. Lie with her: zounds, that's fulsome! Handkerchief - confessions - handkerchief!" (IV.i.35-37), "Impudent strumpet!" (IV.ii.82), "A fine woman, / a fair woman, a sweet woman" (IV.i.173-174), "Goats and monkeys!" (IV.i.258) mark the intensity of emotions Othello is overwhelmed with and suggest that he is entering the final stage of what Lacan called "affectivity's third component" - regression ${ }^{24}$.

From the psychoanalyst's point of view, "the regression is not real; even in language it manifests itself only by inflections, turns of phrase, and 'stumblings so slight' that even in the extreme case they cannot go beyond the artifice of 'baby talk' engaged in by adults" ${ }^{25}$. What is described by Lacan is reflected in Othello's lines, which in Act 5 tend to be alienated from the reality he lives in and seem to belong to the reality Iago helped Othello to create. His speech becomes less emotional, though expressives, which appear in this part, are of a different kind. They become even more abrupt than expressives in the previous acts and in some cases remind of animal sounds, which suggests that Othello drowned in his emotions does not need or is not able to use language any more.

The above analysis of the representation of passion through language in Othello reveals several tendencies used by Shakespeare to create the image of a passionate man. From the point of view of speech act theory, the image of passionate jealousy is constructed with the help of expressives, directives and comissives. In contrast, the language of a rational man is represented through assertives. Moreover the passionate state of the leading character is expressed through emotives and the transition from monological to dialogical structure of the utterances. Lacan's concepts of affectivity in language help to recognize Othello's transformation from a rational person into the passionately jealous human being. Shakespeare's intuitive knowledge of human psychology and its relation to language is confirmed once again.

${ }^{21}$ J. Lacan, A Theoretical Introduction to the Functions of Psychoanalysis in Criminology [in:] J. Lacan, Ecrits: The First Complete Edition in English, transl. B. Fink, New York 2006, p. 120.

22 J. Lacan, The Mirror Stage as Formative of the I Function as Revealed in Psychoanalytic Experience [in:] J. Lacan, Ecrits: The First Complete Edition in English..., p. 80.

${ }_{23}$ M. Wilson, M. Daly, The Man Who Mistook his Wife for a Chattel [w:] The Adapted Mind, ed. J. Barkow, L. Cosmides, J. Tooby, New York 1992, p. 295.

${ }^{24}$ J. Lacan, The Function and Field of Speech and Language..., p. 209.

25 Ibid., 209. 


\section{Bibliography}

\section{Primary source}

Shakespeare W., Othello, London 2001.

\section{Secondary sources}

Buss D.M., Sexual Jealousy, "Psychological Topics” 2013, n 22(2), p. 155-182.

Calderwood J.L., Speech and Self in Othello, "Shakespeare Quarterly" 1987, n 38(3), p. 293-303.

Condoravdi C., Lauer S., Imperatives: Meaning and Illocutionary Force, Colloque de Syntaxe et Semantique a Paris, Universite Paris 8, 21-23 September 2011, conference presentation.

Lacan J., Aggressiveness in Psychoanalysis [in:] J. Lacan, Ecrits: The First Complete Edition in English, transl. B. Fink, New York 2006, p. 82-101.

Lacan J., A Theoretical Introduction to the Functions of Psychoanalysis in Criminology [in:] J. Lacan, Ecrits: The First Complete Edition in English, transl. B. Fink, New York 2006, p. 102-122.

Lacan J., The Function and Field of Speech and Language in Psychoanalysis [in:] J. Lacan, Ecrits: The First Complete Edition in English, transl. B. Fink, New York 2006, p. 197-268.

Lacan J., The Mirror Stage as Formative of the I Function as Revealed in Psychoanalytic Experience [in:] J. Lacan, Ecrits: The First Complete Edition in English, transl. B. Fink, New York 2006, p. 75-81.

Macaulay M., When Chaos Is Come Again: Narrative and Narrative Analysis in Othello, "Style" 2005, n 39(3), p. 259-275.

Searle J., A Classification of Illocutionary Acts, "Language in Society" 1976, n 5.1, p. 1-23.

Searle J., A Taxonomy of Illocutionary Acts [in:] Language, Mind and Knowledge, ed. K. Gunderson, Minneapolis 1975, p. 344-369.

Takahashi H., A Cognitive Linguistic Analysis of the English Imperative: With Special Reference to Japanese Imperatives, Philadelphia 2012.

Wilson M., Daly M., The Man Who Mistook his Wife for a Chattel [in:] The Adapted Mind, ed. J. Barkow, L. Cosmides, J. Tooby, New York 1992, p. 289-322. 